\title{
COVID-19 and Digital Learning in the Dominican Republic: Implications for Marginalized Communities
}

\author{
Katia Diaz \\ Columbia University
}

\begin{abstract}
With COVID-19 placing a strain on its public institutions, the Dominican Republic is attempting to ensure a streamlined digital education process by extending Digital Republic, a past initiative that provides online frameworks and platforms for its students and teachers. However, already long existing issues are exacerbating access to education for vulnerable communities. While past policies included special needs services, the following initiative has yet to provide information on access for disabled students. Likewise, low-income students face financial challenges to gain the resources necessary to thrive during remote learning. The following case study explores the country's education system, how its policies benefit certain groups and negatively impact others. By conducting in-depth policy analysis and interviews, the study analyzes the impact of digital learning during the pandemic among vulnerable communities in the country.
\end{abstract}

\section{Introduction}

The pandemic has placed an undue burden on educational systems in the Caribbean. This is particularly so for countries with resource constraints like the Dominican Republic. With COVID-19 placing a strain on its public institutions, the Dominican Republic is attempting to ensure a streamlined digital education process by providing more digital platform initiatives (Cobo et al., 2020). The digital tools are an addition to Digital Republic, a past initiative that provides online frameworks and platforms for all citizens through the use of technology (Muñoz et al, 2020, p. 83). However, already existing issues are exacerbating access to education, particularly for vulnerable communities. Lack of education access for special needs and low-income students has been a continuous issue. The current education system has seen a divide between urban and rural areas. For example, low-income students residing in rural regions have difficulties accessing quality education and resources compared to their urban, higher-income counterparts (J.A. Rodríguez, Personal Communication, January 29, 2021). Education policies also do not include special needs students. Currently, reforms provide special needs services and programs centered on integration and inclusion (Special Education Directorate \& Vice Ministry of Technical and Pedagogical Services, 2017, p. 4-5). However, these initiatives do not fully address frameworks that do not take into account special needs students in regular classes who have little access to specialized services for specific disabilities (Acevedo, 2016). These issues are part of a larger educational gap revealing years of 
"institutional capacity issues" (UN Convention on The Rights of The Child, 2015, p. 14). With the implementation of digital learning in response to the pandemic, however, existing problems have been exacerbated with marginalized groups being left behind. Once again education access is being denied, either intentionally or unintentionally.

The following case study explores the current education system in the Dominican Republic, how its digital online policies benefit certain groups, and how it reveals underlying effects for other communities. It will explain how COVID-19 exacerbates previous ongoing issues and how the government addresses them. By conducting policy analysis and interviews, the study analyzes the impact of digital learning during the pandemic among vulnerable communities in the country.

\section{Why are Digital Learning Strategies Important Amidst a Pandemic?}

Before delving into the research, it is important to note the impact of Covid-19 in the country. The following case study explores a unique perspective on how Latin American and Caribbean countries are tackling the crisis. Although digital tools like social media apps and platforms have been present in the region, the crisis has pushed many countries to incorporate innovative technological tools and existing media platforms in the classroom (Cobo et al., 2020). By adapting curricula, pedagogical practices, and classroom logistics for online education, teachers and students are using a new form of learning amidst a crisis. The Dominican Republic is only one of many countries incorporating digital learning. However, this innovative solution also has its costs. As a developing nation, the Dominican Republic suffers from structural issues such as lack of access to technology. These problems make it difficult to successfully implement remote learning for all citizens and residents (El Nacional, 2020). This is notwithstanding other faults plaguing the country. According to Paige Cone (2019) from The Ohio State University, the country suffers from "inadequate spending in the education sector, scarce quantity of teachers and low quality of teacher education, delays in formation of secondary schools, and expansive management shortages." Exploring the effects of remote learning impacting vulnerable communities, the study aims to be a first step in exploring alternatives and solutions to address the educational gap in the country. Ultimately, these results could provide an avenue by which quality education could be accessible for all students.

\section{Overview: Education System and "Digital Republic"}

To investigate the country's issues and ramifications, it is also important to explore the Dominican Republic's education system. Currently, the country offers four levels of schooling: pre-primary, primary, secondary, and tertiary (United Nations Educational, Scientific, and Cultural Organization -UNESCO, 2021). Previously, education was compulsory for eight years, providing schooling for children 6-14 years old (OECD, 2008, p. 29). However, compulsory education has been recently extended to 13 years (The 
National Institute of Education Planning \& UNESCO, 2019, p. 2) For secondary education, children aged 14-18 receive four years of additional schooling to strengthen skillsets. This includes general education within the first cycle while vocational, continuing general education, and art options are in the second cycle. There are also two additional systems in place, or subsystems, that focus on adult education and children with special needs. Each level of education is coordinated through three agencies:

1. The Ministry of Education, (Secretaría de Estado de Educación -SEE or MINERD) which helps to coordinate primary and secondary schools.

2. Ministry of Higher Education, Science and Technology (Secretaría de Estado de Educación Superior, Ciencia y Tecnología-MESCyT) which focuses on colleges and universities as well as research institutions concentrating on technological, biological, industrial, and agricultural advances. And,

3. The National Institute of Professional and Technical Training (Instituto Nacional de Formación Técnico Professional) that centers on alternative schooling for nontraditional students and technical/vocational training (Organization for Economic Cooperation and Development-OECD, 2008, p. 29-32)

Currently, there are 2.7 million students who have matriculated at the start of the academic school year as of 2018 (National Office of Statistics, 2019).

While the education system provides a basic approach to education, the country has made a series of reforms over the years to improve. Its most recent, the Institutional Strategic Plan 2017-2020 (Plan Estratégico Institucional), has yielded great results. According to the evaluation report published by MINERD, school literacy has increased with 999, 026 adult individuals obtaining literacy skills thanks to the program National Plan of Literacy Quisqueya Learn with You (Alfabetización Quisqueya Aprende Contigo) (MINERD, 2018 p. 37). Additionally, the report found that more students aged 15 have continued their education from 8.6 years to 9.18 years (MINERD, 2018 p. 36-37). These achievements are a testament to the various programs established including a focus on early childhood development centers and nutritional programs, among other initiatives (MINERD, 2018, p. 94).

Alongside these measures, the government aims to improve its system through online educational tools available to students and teachers. This is where República Digital or the Digital Republic program comes in. In response to the 2030 Sustainable Development Goals, Digital Republic aims to provide access for all citizens while "enabling economic and social development" through the use of technology (Muñoz et. al, 2020, p. 83). The program extends beyond the educational system with information and communication technologies (ICTs) to be incorporated within the government (for transparency purposes) and includes gender equity and "social inclusion" (Muñoz et. al, 2020, p. 83-84). One of its purposes is to bridge the "digital divide" among vulnerable populations who do not have access (i.e., low-income families, those from rural areas, and families with 
"lower levels of education") (Dominican Republic Government, p. 10). So far, the program offers projects including broadening WIFI access, capacity-building classes on technology for women and low-income individuals, and computer access for children and their families. The results of the program have been met with mixed reviews, however, with some officials calling it a success in closing the digital divide while publications questioning the limitations of the program's outreach to successfully provide access to all communities. For example, the publication Diario Libre notes that these projects have only reached $5 \%$ of the student population (1 in 4 households) compared to official statistics from the Dominican Republic's Sustainable Development Executive Summary reporting that almost $90 \%$ of residents in the country have access to mobile technology (Dominican Republic Government, p. 10)

With the onset of COVID-19, however, virtual learning became a priority. Extending Digital Republic, the government implemented a series of initiatives to adapt the educational system into online learning and provide families with the tools they need to continue their education despite a worldwide pandemic. These initiatives include expanding free WIFI up to "1,000 access points," a national education portal where educational content can be accessed by grade level, and social networking apps like WhatsApp which help to connect students and teachers throughout their remote learning (Cobo et al., 2020).

In addition to these resources, the Ministry of Education supported approximately 2,000 vulnerable families by providing sanitary kits at educational centers (Listin Diario, 2020). This initiative was in collaboration with the organization World Vision and the General Directorate for Community Participation (Dirección General de Participación Comunitaria) and the Office for International Cooperation (Oficina de Cooperación Internacional-OCI). Sixty centers distributed the kits in the following provinces: Santo Domingo, San Cristóbal, Monseñor Nouel, La Vega and Santiago (Listin Diario, 2020). Aside from the kits, World Vision also provided informational videos that can help parents facilitate their homes into educational spaces for their children.

While these initiatives have greatly benefitted some communities, other groups are being marginalized-whether through exclusionary practices or inaccessible methods. Thus, the educational system has two underlying issues that have become more apparent during the pandemic: the socio-economic divide within rural and urban schools among wealthier and low-income students, and lack of access and guidance for children with disabilities.

\section{Urban vs. Rural: Socio-Economic Divide within Digital Learning Processes}

One of the most notable inequalities within the Dominican Republic's education system is the socio-economic divide between schools in the cities and institutions in rural areas where access is less defined. For example, secondary schools have a lower attendance in 
rural areas compared to urban zones (OECD, 2008, p. 150). According to research by Nidia Beatriz Columna Pérez (2020), the attendance rate for general urban areas is " $9.53 \%$, while rural area rates are as high as $19.36 \% "$ (p. 2). Keeping in mind discrepancies between the areas, the researcher also emphasizes how both urban and rural provinces have no indicators to provide analysis of policies. Each district and territory are classified "homogenously" by "residence zone" without any other factors making their analysis of policies difficult to discern (Pérez, 2020, p. 2). How then, does socio-economic status link to inequalities in the education system?

Crucial prevalent issues stem from socio-economic divides among the public and private schools, generating a gap between lower-income and higher-income families. With more privileges than their public counterparts, private schools are enjoyed by those who can afford it with higher-income families enrolling often than lower-income students (OECD, 2008, p. 167). There are few resources and inadequate facilities in "marginalized urban and rural areas" (UN Convention on The Rights of The Child, 2015, p. 14). Unlike public schools, private schools have more resources and better-trained staff, providing an advantage in education quality for those who can attend. With the pandemic, however, resources have been spread thin. According to R. Olaechea, a private school coordinator in the city of Santiago, private schools have been ahead in the curriculum than most public schools since the pandemic (Personal Communication, February 5, 2021). Governmentfunded schools started online learning in November compared to private schools which started in September of last year. This discrepancy is only one example of the advantages of private schools which regularly provide extra hours of schooling to cover more of the curriculum needed. Private schools generally end their classes at 2:00-2:30 p.m. while public schools end at noon. Aside from regular classes, the coordinator emphasized, teachers provide additional hours for tutoring as needed. Not to mention, most parents whose children attend private schools have the money and resources for virtual learning including providing them with WIFI access and computers. Even with the Digital Republic's initiatives to bridge that gap by offering internet and computers, this project is not reaching far enough to those who need it the most. This advantage to one group only increases the gap between private and public schools with around $80 \%$ of students in public schools falling behind in the academic year (Garrido, 2021).

Yet, much like their public school counterparts, rural areas also suffer from a similar fate. The school coordinator noted that rural areas as far as the South close to the Haitian border continue to have limited technological access for learning. Her assessment is not only true but troubling. In a large study conducted by the International Organization for Migration (IOM) and other partner organizations (2020), 16\% of those who are taking classes remotely have not been able to continue their education, emphasizing that $40 \%$ of individuals among this group live in "border territories" (IOM et. al, 2020, p. 1). How, then, do these differences affect school productivity and performance? 
In this way, one can see the differences in performances based on economic status. Looking at previous PISA results, one can view how income was a strong "predictor" for performance, at least in math and science compared to reading which found little correlation (Avvisati et al.,-2019, p. 3). However, disparities in access and education quality can be seen among different populations. For example, there is a larger concentration of low-performing students in one area compared to other areas with highperforming students. According to the assessment, there is a lower chance for a disadvantaged student to be enrolled in a top-performing school (around 15\%). These "clusters" of students, as indicated in the report, shows where resources have also been distributed. Disadvantaged schools often report more teacher and resource shortages ( $31 \%$ of students enrolled with reports submitted by principals) while advantaged schools have also experienced similar issues but to a lesser extent $(17 \%$ of students enrolled with reports submitted by principals) (Avvisati, et. al, 2019, p. 5). Yet, teachers are more certified in disadvantaged schools than advantaged ones, although they have less experience (Avvisati, et. al, 2019, p. 5).

While these disparities remain a fixture in the education system, COVID-19 exacerbated them further. In an interview with J.A. Rodríguez, a public teacher for a language immersion program, the instructor noted how family members and their children struggled to keep up with schooling during the pandemic (Personal Communication, January 29, 2021). At first, there were "no classes at all," he said. Once the Ministry of Education implemented television programs with homework packets, however, it seemed that a structure was put into place to help children continue their schooling. At the time, the government spent around $\operatorname{RD} \$ 1,575,043,073$ to fund 44 broadcasting companies that would establish educational programming throughout the country (Servicios de Acento.com.DO, 2021). While some students benefited from the programming, others continued to struggle to keep up with schooling despite its implementation. J.A. Rodríguez emphasized that not every family has a television in their home which left some students unable to finish their homework. Others could gain access by going to the houses of their friends or family where television was available. For example, the interviewees' cousin and his family are the only household in the neighborhood to own a television. Most of the students nearby go to their house to watch the educational programs to complete their tasks. Ultimately, around $26 \%$ of students were able to effectively benefit from the television programs (Garrido, 2021). Access to education and the resources available like the internet and technology is still a "privilege," as the public teacher emphasized.

Unfortunately, these testimonials are not a surprise considering the struggles public schools face since the start of the pandemic. According to a report by (2020), approximately $91 \%$ of students in public schools utilize digital tools like WhatsApp on a regular basis to continue their education with "four hours or less" spent on tasks for classes. However, $41 \%$ of these students are only able to gain just around "two hours" of schooling (Garrido, 2021). While MINERD's plans to implement television programs were 
well intentioned, its execution did not bring about the desired change the Ministry hoped for. The results were once again mixed. For some families with only one television and multiple children at different stages in their education, the programs were ineffective (Féliz, 2020). Reflecting on the implementation, J.A. Rodríguez noted how the television programs were well made but left plenty of students with little motivation to learn. Not to mention, he said, the programming did not reflect the curricula implemented in schools (Personal Communication, January 29, 2021).

The execution may be problematic, but the country's digital strategies also did not consider the gap in access among different students. In a recent joint report by the Dominican Institute of Evaluation and Research for Education Quality (Instituto Dominicano de Evaluación e Investigación de la Calidad Educativa-IDEICE) and local organizational network The Observatory Toward the Implementation of the Convention on The Rights of Persons with Disabilities (2020), there is a gap among the use of technology by students (p. 4-5). For example, the report outlined how $79 \%$ of students reported having access to internet, leaving behind 450,000 students who do not have access (IDEICE \& The Observatory, 2020, p. 5). Additionally, the report noted how some students may have the technology but not the training to use the tools effectively. As a result, digital learning strategies have been ineffective so far in tackling the existing issues within the country's education.

\section{Left Behind: Exclusionary Practices Affecting Special Needs Students}

While the education system has suffered from the unequal distribution of resources, the system fails to include those with special needs or who have a disability. In turn, exclusionary practices persist in a country with 1,160, 847 individuals living with a disability (The Observatory, p. 2). According to The Observatory, the education system lacks proper practices to address individuals with disabilities (p. 4). For example, children with disabilities are being turned away at schools, denying them access to primary education. Facilities in public and private schools are not structurally equipped to accommodate those with physical disabilities. Additionally, there are few teachers with little special education training such as individuals familiar with Sign language. Not to mention, Braille is hardly available for individuals who are blind or visibly impaired (The Observatory, p. 4-5). These inadequacies reflect a long-standing education system unable to provide inclusionary practices into their classrooms although these issues are currently being addressed by the government.

In an interview with a public official from MINERD's Special Education Directorate, the publication Metro found that at the time "around 48\% of public schools [had] students with disabilities in their classrooms" (Acevedo, 2016). While this number was a large percent of students in need of special services, this statistic showed that schools were illequipped to provide an inclusive education to students with disabilities; an issue that the government was well aware of. A previous study conducted by the government found 
that " $59 \%$ of educational centers were unable to incorporate inclusive pedagogical practices that could help students in their learning and development" (Acevedo, 2016). In response to these issues, improvements were made but problems continue to surface even today. Nevertheless, incorporating a strategy perhaps may be far difficult considering the infrastructure available. Below is a list of the challenges exacerbated by the pandemic that children with disabilities continue to face:

- A need for a support team of specialists necessary to meet a child's needs.

- The lack of supporting tools and adequate technology to follow their classes from home.

- Difficulties for family mediation, care and personal attention. Particularly, when the country still does not have the legal and social framework that facilitates care and conciliation.

- The economic difficulties experienced by families and that are aggravated by the care of children and adolescents with disabilities.

- A need for a protocol for specialists, health personnel and caregivers of children and adolescents. (La Red Dominicana, 2020)

Ideally, teachers would be able to integrate special needs students within their classrooms by evaluating each child's learning style, adjusting curriculum as needed and planning learning sessions that focus on a child's "cognitive, psychological, and social development (Flores \& Hernández, 2016, p. 18). Placing inclusive frameworks into action, higher education institutions in the country are providing certifications and master's programs in diversity and inclusion as well as special education (Peláez \& Ramirez, p. 14). These initiatives are being established in response to Law No. 5-13 which stipulates that the National Council of Disability (Consejo Nacional de Discapacidad -CONADIS) must partner with academic institutions to provide training in special education (Peláez \& Ramirez, p. 14). Currently, institutions like the Autonomy University of Santo Domingo (La Universidad Autónoma de Santo Domingo) and the Pontifical Catholic Mother \& Teacher (La Pontificia Catolica Madre y Maestra) offer electives or pre-requisites regarding special education needs and diversity (Peláez \& Ramirez, p. 14-15).

With the foundation in place to develop teachers knowledgeable in special education, the government has implemented other reforms through the Institutional Strategic Plan 20172020. Currently, the Ministry of Education has implemented the Resource Center for The Attention Towards Diversity (Centro de Recursos para la Atención de Diversidad -CAD) which aims to "promote education access for students with special needs - without exclusion toward any condition of any kind" (MINERD, 2018, p. 128). The Centers have "interdisciplinary teams" which provide "psycho-pedagogic counseling in 516 primarylevel educational centers" (MINERD, 2018, p. 128). A total of 32,955 students benefited from the program with 1,916 psycho-pedagogical evaluations being implemented, and language evaluations conducted for up to 860 students (MINERD, 2018, p. 129). Furthermore, CAD's implemented support spaces to help students struggling with 
reading and comprehension and provided resources and specialized teachers for students with visual impairments (MINERD, 2018, p. 129). There are also other programs with partnered agencies providing further training for individuals working with special needs children. Among these programs is the partnership of National Institute of Education and Training of the Magisterium (Instituto Nacional de Formación y Capacitación del Magisterio -INAFOCAM) and the National University of Pedro Henríquez Ureña (Universidad Nacional Pedro Henríquez Ureña-UNPHU). This project offered a series of workshops for teachers and pedagogical experts working in the special education field (INAFOCAM, 2017). These reforms are a big improvement, considering that just two years earlier the government reported a shortage of untrained staff with $64 \%$ of public schools reporting not having any personnel with credentials in special education (Acevedo, 2016).

Looking at these policies and programs, it seems like the Dominican Republic is on its way to providing inclusive education for students with special needs. Yet, reports of unequal access among this vulnerable group persists - especially now more than ever with the pandemic forcing students with disabilities to cease their education.

Currently, research on special education during COVID-19 is limited. However, according to a report by the Economic Commission for Latin America and the Caribbean (ECLAC) and UNESCO (2020), the pandemic has exacerbated and highlighted these inequities in the Latin American and Caribbean region. Particularly, the risk of "disengagement and dropping out of school" is a particular concern (p. 14). More troubling are the COVID-19 online platforms that do not address special education curricula or services, even with government efforts planning to include special needs children in their school reopening strategies (Garcia, 2020, p. 15). Furthermore, MINERD's Special Education Directorate has been conducting an assessment to identify what services children with disabilities need during this time (Ozuna, 2020). Although another well-intentioned effort in part by the government, this lack of awareness to include special needs students earlier on shows that services were not even considered when the agency launched its remote learning strategy. As a result, many educational staff who work with students with special needs had no choice but to rely on their "own resources and ingenuities" to help their students continue their education (Ozuna, 2020).

It seems like implementing concrete educational methods for students with special needs and individuals with disabilities continues to be a problem. Yet, there have been improvements since the implementation of the Institutional Strategic Plan 2017-2020. Even prior to the initiative's inception, there were efforts toward inclusivity in the form of cross-collaborative programs that tailor to specific needs or public and non-profit initiatives (pre-pandemic). For example, the Dominican Association of Rehabilitation (Asociación Dominicana de Rehabilitación) and CONADIS continue to provide resources, legal support, educational training, and workshops for individuals with disabilities. However, during the pandemic, there are no inclusionary methods provided across the 
board in the classroom. Researcher Katherine Hernández Morales (2021) underscored the need for officials to ensure full inclusivity where agencies "continue developing and adapting curricula and didactic materials, hire specialists for distinct needs, and provide adequate spaces in education centers for greater access" (p. 79). Once again, the realities of implementing inclusive education are far from perfect, leaving special needs students behind in their education despite the progress.

\section{Discussion}

The Covid-19 crisis has brought a different dimension onto education systems - one that could be considered a double-edged sword. In the case of the Dominican Republic, digital learning strategies have proven to benefit some students during the pandemic. However, it also laid bare the inequalities that continue to persist in the country. It divided the education system into the have's and have not's, with low-income students in rural regions and public school students struggling to gain access to digital tools and traditional media. For those with disabilities, accommodations and services were not considered during the government's efforts, leaving teachers and students to fend for themselves. While progress has been made over the years, the country's institutional capacity to provide quality education for all has been call into question again. Yet, there is a silver lining to the crisis. Recognizing the importance of digital tools, both policy officials and teachers understand that technology should be incorporated regularly into the classroom moving forward. However, the next question to consider is how we can implement these tools in an inclusive way for all communities. This research is only one step in addressing this question.

Given the limited time frame in this study, future research must take into account the rapid changing policies and programs being implemented in response to the pandemic. These assessments must be flexible in monitoring best practices while ensuring that results are updated on a regular basis. Furthermore, other vulnerable communities that have been impacted should have their own assessments made. For example, Haitian migrants and individuals of Haitian descent should have their own separate study. Further research on this should also consider the impact of Covid-19 and access to their education. Likewise, a gender perspective on education access during this time should also be evaluated.

As it stands, this study only reflects one aspect of the education system. With only a few on-the-ground interviews and extensive policy analysis, the study is limited. More indepth research should include implementing surveys in public and private schools as well as in rural and urban areas to gauge further improvement or lack thereof in access to resources. Additionally, more interviews with teachers, parents, and students should also be conducted to provide a more holistic view of the issue. Yet, more importantly, researchers must keep in mind the cultural sensitivity of the case study. Given the socio-

political and institutional climate in the country, researchers must focus their study on a 
local perspective away from the Eurocentric ideals and frameworks used as benchmarks to compare low-income countries. In doing so, the study can be a fair and balanced approach to the country's education efforts.

\section{Conclusion}

Remote learning is here to stay. Yet, whether it is for better or worse remains to be seen. As we continue to face our new normal, countries like the Dominican Republic have no choice but to adapt with new technological tools to help its residents continue their education. However, officials must solve how they can successfully implement digital learning strategies in the country. It is imperative that no person is denied their education because of the barriers in place. With Covid-19 leaving its mark, the ripple effects of the Dominican Republic's education system are not only visible but exacerbated. If education initiatives can address these effects during its digital learning programs, students can finally obtain a quality education that is beneficial for their growth and development. In doing so, a better education can be achieved for all students in the country now and into the future.

Katia Diaz is a graduate of Columbia University's Graduate School of Arts \& Sciences. Previously, she was a Fulbright U.S. Student Scholar teaching college students English in the Dominican Republic. Katia has over five years working in national and local governments. Currently, she works in Communications at an international foundation. 


\section{References}

Acevedo, C. (2016, April 13). Hablemos de inclusión uma las escuelas de RD. Metrord. Retrieved From: https://www.metrord.do/do/noticias/2016/04/13/hablemosinclusion-escuelas-rd.html

ADP advierte Ministerio de Educación no está preparado para dar clases virtuales por coronavirus. (2020, March 17). Diario Libre, Salud. Retrieved From: https:/www.diariolibre.com/actualidad/salud/adp-advierte-ministerio-deeducacion-no-esta-preparado-para-dar-clases-virtuales-por-coronavirusNC17739765

Avvisati, F., Echazarra, A. Givord, P., \& Schwabe, M. (2019). Country Note: Programme for International Student Assessment (PISA): Results from PISA 2018. Organization for Economic Cooperation and Development (OECD). https://www.oecd.org/pisa/publications/PISA2018_CN_DOM.pdf

Cobo, C., Hawkins, R., \& Rovner, H. (2020, March 31). How countries across Latin America use technology during COVID19-driven school closures. World Bank Blogs. Retrieved From: https://blogs.worldbank.org/education/how-countriesacross-latin-america-use-technology-during-covid19-driven-school-closures

Cone, P. (2019, February 16). Higher Education in The Dominican Republic: Access, Equity, \& Opportunity. The Ohio State University. Retrieved From: https://u.osu.edu/cone21hseportfolio/2019/02/16/higher-education-in-thedominican-republic-access-equity-and-opportunity/

Dominican Institute of Evaluation and Research for Education Quality and The Observatory Toward the Implementation of the Convention on The Rights of Persons with Disabilities. (2020). Educación Dominicana uma el Contexto de la Covid19. https://ideice.gob.do/documentacion/publicaciones-msg-set-id-1-art-p1-132educacion-dominicana-en-el-contexto-de-la-covid-19

Dominican Republic Government. Primer Informe Voluntario (INV) de la Republica Dominicana sobre los Objetivos de Desarrollo Sostenible y la Agenda 2030 para el Desarrollo Junio de 2018. Executive Summary. UN Sustainable Development Archive.

https://sustainabledevelopment.un.org/content/documents/20170Executive_Sum mary_Domincan_RepublicEn_.pdf

Economic Commission for Latin America and the Caribbean (ECLAC) and Regional Bureau for Education in Latin America and the Caribbean of the United Nations Educational, Scientific, and Cultural Organization (OREAL/UNESCO) (2020). Education in the time of COVID-19. United Nations. 
https://repositorio.cepal.org/bitstream/handle/11362/45905/1/S2000509_en.pdf

Educación Especial. Dominican Association of Rehabilitation.

https://www.adr.org.do/index.php/programas-especiales/educacion-especial

El 90\% de estudiantes de hogares dominicanos accedieron a clases virtuales a través de. Diario Libre, Clases Virtuales. https://www.diariolibre.com/actualidad/educacion/el-90-de-estudiantes-dehogares-dominicanos-accedieron-a-clases-virtuales-a-traves-de-whatsappLF21715824

Féliz, B. (2020, November 3). Reto inicio de clases: uma TV para 155ários niños y aún sin cuadernillos. Hoy, El Páis, Portada, Titular. Retrieved From: https://hoy.com.do/reto-inicio-de-clases-una-tv-para-varios-ninos-y-aun-sincuadernillos/

Flores, D. R., \& Hernández, C.N. (2016). Capacitación Profesional Docente: Realidades de la Educación Inclusiva. Cuaderno de Pedagogía Universitaria. Vol. 13, No. 26., p. 1525.

https://cuaderno.pucmm.edu.do/index.php/cuadernodepedagogia/article/view/2 $60 / 249$

Garantizar el derecho a una educación inclusiva también en tiempos de COVID-19. (2020, November 11). La Red Dominicana. Retrieved From: https://lareddominicana.org/noticias/garantizar-el-derecho-a-una-educacioninclusiva-tambien-en-tiempos-de-covid-19/

Garcia, V. R. (2020). El Desafío del Regreso A Clases En Medio del Coronavirus. Observatorio Político Dominicano (OPD-FUNGLODE). https://issuu.com/opdfunglode/docs/estudio_del_opdfunglode_el_desaf_o_del_regreso_a_

Garrido, S. (2021, March 11). Pandemic highlights education inequities in the Dominican Republic. The Berkeley Beacon. Retrieved From: https://berkeleybeacon.com/pandemic-highlights-education-inequities-in-thedominican-republic/

Hincapie,D., Duryea, S., \& Hincapié, I. (2019). Education for All: Advancing Disability Inclusion in Latin America and the Caribbean. Inter-American Development Bank. https://publications.iadb.org/en/education-all-advancing-disability-inclusionlatin-america-and-caribbean 
International Organization for Migration. (2020, November 10). IOM Aids COVID-impacted communities on Haiti-Dominican Border and Worldwide. [Press Release]. https://reliefweb.int/report/dominican-republic/iom-aids-covid-impactedcommunities-haiti-dominican-border-and-worldwide

International Organization for Migration, Joint United Nations Programme on HIV and AIDS (UNAIDS), United Nations Children Fund (UNICEF), United Nations Dominican Republic, \& United Nations Population Fund (UNFPA). (2020). Impacto de COVID-19 en la educación: 2 da encuesta sobre el impacto socioeconómico de la COVID19. https://dominicanrepublic.un.org/es/93130-impacto-de-covid-19-en-laeducacion-2da-encuesta-sobre-el-impacto-socioeconomico-de-la-covid

Morales, K.H. (2020). La educación antes y durante la pandemia del Covid-19: tejiendo redes en médio de la desigualdad y la inclusión social en la República Dominicana. CAMINHOS DA EDUCAÇÃO: diálogos, culturas e diversidades. https://docs.google.com/document/d/1evQsnnyZMQeSOal1uXi8ccSQi6o1cXaxk4zqY37rK4/edit?usp=sharing

Muñoz, D. , Sánchez-Castillo, G. , De la Rosa-Feliz, C. , \& Puentes, A. (2020). ICT In Education: The Situation of Dominican Republic. In Tomczyk, Ł. \& Oyelere, S. S. (eds.). ICT for learning and inclusion in Latin America and Europe. Cracow: Pedagogical University of Cracow.

https://www.researchgate.net/publication/339178227_ICT_IN_EDUCATION_TH E_SITUATION_OF_DOMINICAN_REPUBLIC

Narran dificultades en clase a distancia. (2020, November 6). El Nacional, Actualidad. Retrieved From: https://elnacional.com.do/narran-dificultades-en-clase-adistancia/

National Council of Education. Ministry of Education. (2018). Institutional Strategic Plan 2017-2020. Sistema de Información de Tendencias Educativas en America Latina (SITEAL). International Institute of Education Planning \& United Nations Educational, Scientific, and Cultural Organization (IIPE-UNESCO). https://siteal.iiep.unesco.org/sites/default/files/sit_accion_files/do_0350.pdf

The Observatory of the Implementation of the Convention on The Rights of Persons with Disabilities. Association of Persons with Physical-Motor Disabilities, Pedro Francisco Bonó Center, Circle of Women with Disabilities, \& Dominican Foundation of The Blind. Rights of persons with a disability in the Dominican Republic: Universal Periodic Review. Retrieved https://drive.google.com/file/d/1tghapFZxUvX5ylJObe5S4IhCSovqloon/view?usp =sharing 
National Office of Statistics. Ministry of Education. (2019). Estudiantes matriculados a inicio del año escolar por año lectivo, según sector y nivel, 2009-2010/2017-2018. Características de la población escolar. [Data Set] https://archivo.one.gob.do/sociales/educacion/caracteristicas-de-la-poblacionescolar

Organization for Economic Cooperation and Development (OECD). (2008). Reviews of National Policies for Education in the Dominican Republic https://www-oecd-ilibraryorg.ezproxy.cul.columbia.edu/docserver/9789264040823-

en.pdf?expires=1592946276\&id=id\&accname=ocid177456\&checksum=DB990B593 F8C50521101521689BCAA1F

Ozuna, A. (2020, November 27). Educación, que ningún niño quede fuera. Diario Libre, Estilos. https://www.diariolibre.com/estilos/buena-vida/educacion-que-ningunnino-quede-fuera-MJ22904954

Peláez, N. K., \& Rámirez, L. G. La Importancia de la Capacitacion Docente en El Manejo de Necesidades Educativas Especiales. [Essay, Iberamerican University]. https://repositorio.unibe.edu.do/jspui/bitstream/123456789/412/1/18-0341_TF.pdf

Pérez, N. B. (2020). Teachers' Experiences in Schools that Serve Rural Communities in The Dominican Republic: Their Readiness to Respond to Challenges. [Doctoral Dissertation, Western Michigan University].

https://scholarworks.wmich.edu/cgi/viewcontent.cgi?article=4607\&context=disse rtations

Servicios. Consejo Nacional de Discapacidad (CONADIS).

http://conadis.gob.do/category/servicios/

Servicios De Acento.Com.Do. (2021, January 9). Inversión en clases por televisión y radio alcanza los RD\$5 mil millones. Acento, Actualidad. Retrieved From: https://acento.com.do/actualidad/costo-clases-por-television-aumento-de-3-a-5mil-millones-de-pesos-por-nuevas-adjudicaciones-8900141.html

Special Education Directorate \& Vice Ministry of Technical and Pedagogical Services. (2017). Ministry of Education. Cúal es la Historia de la Educación Especial en la República Dominicana. https://www.ministeriodeeducacion.gob.do/docs/direccionde-educacion-especial/1ORA-preguntas-frecuentes-a-la-direccion-de-educacionespecialpdf.pdf

The National Institute of Education and Training of the Magisterium. (2017, April 10). INAFOCAM y UNPHU concluyen cuarta versión del Diplomado en Educación Especial. Noticias. https://inafocam.edu.do/index.php/noticias/item/270- 
inafocam-y-unphu-concluyen-cuarta-version-del-diplomado-en-educacionespecial

The National Institute of Education Planning \& The United Nations Educational, Scientific, and Cultural Organization (UNESCO). (2019). Dominican Republic: Country Profile. Sistema de Información de Tendencias Educativas en America Latina (SITEAL).

https://siteal.iiep.unesco.org/sites/default/files/sit_informe_pdfs/dpe_r._dominica na_25_09_19_0.pdf\#: :text=El\%20sistema\%20educativo\%20de\%20la,promulgadas $\% 20$ entre $\% 202013 \% 20 y \% 202017$

United Nations Convention on The Rights of The Child (CRC). (2015). Concluding observations on the combined third to fifth periodic reports of the Dominican Republic. [UN Treaty Body Database].

https://tbinternet.ohchr.org/_layouts/15/treatybodyexternal/Download.aspx?sym bolno $=\mathrm{CRC} \% 2 \mathrm{fC} \% 2 \mathrm{fDOM} \% 2 \mathrm{fCO} \% 2 \mathrm{f} 3-5 \&$ Lang=en

United Nations Educational, Scientific, and Cultural Organization (UNESCO). (2021). Education and Literacy. [Country Report Database].

http://uis.unesco.org/en/country/do 